\title{
Establishing a Different Dimension of Citizen Security: The Case for Special Protection for Whistleblowers
}

\author{
David Lewis $^{1}$, Joshua Castellino ${ }^{2}$ \\ ${ }^{1}$ Law Department, Middlesex University, London, UK \\ ${ }^{2}$ School of Law, Middlesex University, London, UK \\ Email: D.B.Lewis@mdx.ac.uk, J.Castellino@mdx.ac.uk
}

Received September $4^{\text {th }}, 2013$; revised October $6^{\text {th }}, 2013$; accepted November $5^{\text {th }}, 2013$

\begin{abstract}
Copyright @ 2013 David Lewis, Joshua Castellino. This is an open access article distributed under the Creative Commons Attribution License, which permits unrestricted use, distribution, and reproduction in any medium, provided the original work is properly cited.
\end{abstract}

\begin{abstract}
The notion of citizens' security has usually been viewed primarily as a binary relationship between the State and the citizen in a Rousseauesque interpretation. This article argues for a broader conception of citizens' security focussing on the right to "blow the whistle" in an employment context. We believe that with the growing importance of global business in society it is imperative that special measures are designed for this important class of citizens. A failure to do so, in our opinion, is likely to harm the maintenance of effective protection, especially in developing countries, to the detriment of citizens' security.
\end{abstract}

Keywords: Employment Law; Freedom of Expression; Corporate Wrongdoing; Corporate Liability

\section{Introduction}

The Universal Declaration of Human Rights unveiled in 1948 sought to identify a broad category of rights that would be available to protect every individual on the basis of their being part of the human community ${ }^{1}$. The rights envisaged were purported to guarantee their inherent dignity and worth ${ }^{2}$. However, as it had been apparent in the centuries prior to the Declaration, there existed and continued to exist, a fundamental difference between the de facto access to rights and their de jure articulation. In the context of the history of international law, the attempt to bridge this difference is visible in the many lex specialis regimes that have been created in order to protect specific categories of individuals who are classifiable as members of a definable group. Special regimes have been designed to protect women and children in the context of war (Durham 2002) ${ }^{3}$, and minorities regarded as particularly vulnerable owing to their location within states that did not fully represent them ${ }^{4}$. The aim of such measures was to create an extra layer of citizen protection in a bid to overcome the difficulties of access to rights that members of such groups faced ${ }^{5}$.

Despite the re-articulation of the modern agenda of human rights as rights applying equally to every individual, the trend towards recognising lex specialis has continued. Among the

${ }^{1}$ For general reading on the Universal Declaration see Morsink, (1999) (2009).

${ }^{2}$ There has been some critique about the individuality (as opposed to collective nature) of the protections enshrined here, see Donoho (1990-1991); Lewis (1995) and An-Na'im, Madigan and Minkley (1997).

${ }^{3}$ There are 42 provisions referring to women in the 1949 Geneva Conventions on the Laws of Wars and the 1977 Additional Protocols see Gardam \& Jarvis (2001). For an articulation of child rights during the League of $\mathrm{Na}$ tions see Geneva Declaration of the Rights of the Child of 1924.

${ }^{4}$ Among the most famous ancient treaty that is cited is The Promise of St. Louis of France, 1250. See Thornberry (1991), especially Chapter I.

${ }^{5}$ For more on access to justice, which underpins this issue see Rhode (2004) 1-19, 103-120; Francioni (2007). pantheon of such protection are instruments pertaining to indigenous peoples ${ }^{6}$, minorities ${ }^{7}$, women ${ }^{8}$, children $^{9}$, migrant workers (documented and undocumented), ${ }^{10}$ refugees $^{11}$ and the disabled $^{12}$. In each context international treaties have been signed and ratified containing a series of general human rights, a list of specific rights distinct to the class of persons in question, and in some cases, an additional mechanism designed to

${ }^{6}$ See Convention Concerning Indigenous \& Tribal Peoples in Independent Countries (ILO No. 169); United Nations Declaration on the Rights of Indigenous Peoples (2007); Proposed American Declaration on the Rights of Indigenous Peoples (1997).

${ }^{7}$ Declaration on the Rights of Persons Belonging to National or Ethnic, Religious or Linguistic Minorities (1993).

${ }^{8}$ Convention on the Elimination of All Forms of Discrimination against Women (1981); Optional Protocol to the Convention on the Elimination of All Forms of Discrimination against Women (2000); Declaration on the Protection of Women and Children in Emergency and Armed Conflict (1974).

${ }^{9}$ Convention on the Rights of the Child (1989); Convention concerning the Prohibition and Immediate Action for the Elimination of the Worst Forms of Child Labour (ILO No. 182); Optional Protocol to the Convention on the Rights of the Child on the involvement of children in armed conflicts (2000) Optional Protocol to the Convention on the Rights of the Child on the sale of children, child prostitution and child pornography (2000). In addition there are also guidelines concerning juvenile offenders such as United Nations Rules for the Protection of Juveniles Deprived of their Liberty, (1990); United Nations Guidelines for the Prevention of Juvenile Delinquency (The Riyadh Guidelines) (1990) and the United Nations Standard Minimum Rules for the Administration of Juvenile Justice ("The Beijing Rules") (1985).

${ }^{10}$ International Convention on the Protection of the Rights of All Migrant Workers and Members of Their Families (1990).

${ }^{11}$ Convention relating to the Status of Refugees (1954); Protocol Relating to the Status of Refugees (1967); Guiding Principles on Internal Displacement (1998); and the Cartagena Declaration on Refugees (1984).

${ }^{12}$ Declaration on the Rights of Disabled Persons (1975); International Convention on the Protection and Promotion of the Rights and Dignity of Persons with Disabilities (2006); First Optional Protocol to the International Convention on the Protection and Promotion of the Rights and Dignity of Persons with Disabilities (2006). 
overcome the problem of the groups' lack of access to general rights (Alston, 1996). Most recently, the trend has also included the creation of lex specialis at European level, for human rights defenders, on the grounds that their rights are particularly difficult to guarantee ${ }^{13}$.

This article argues that in the context of developments in the South, more specifically the ever growing prominence of global business, whistleblowers should be treated as a special class of individual with a lex specialis designed to guarantee the full recognition of their human rights and to safeguard their particular role in defending human rights in the workplace. The opening section discusses the nature and scope of whistleblowing and offers reasons why whistleblowers should receive special protection. The second section seeks to clarify the extent to which international human rights law has generated categories of lex specialis, outlining their rationale and prime substantive content. The final section outlines precedents from around the world where this class of individuals has been given special protection, with a view to: 1) supporting the argument for their special protection through concrete examples, and 2) highlighting the kinds of issues that ought to be considered within the attempt to frame more universal regimes of protection.

\section{Whistleblowers as a Particular Class in Need of Protection}

The popular media regularly provide stories about individuals who, often under threat of losing their job, opt to "do the right thing" in seeking to address a wrong perpetrated by their employer or other workers. Thus the whistleblower is frequently portrayed as facing the moral dilemma of wanting to raise a concern but being aware of the personal price that may have to be paid. In addition to this classical view of whistleblowers, there are workers whose jobs require them to perform a monitoring role, for example auditors, human rights defenders and trade unionists. To make a clear-cut case for the special protection of whistleblowers it is necessary to identify precisely who ought to benefit from such protection. This will be attempted in the following section.

\section{Some Definitional Issues}

A broad definition of whistleblowing would encompass disclosures of malpractice, as well as illegal acts or omissions. In the UK the charity Public Concern at Work (PCAW) offers help and free legal advice to people who have "a concern that something seems to be seriously wrong, illegal or dangerous which threatens the public interest"14. One obvious problem is the lack of consensus about what constitutes "wrongdoing"15. Because there is no universally accepted definition of whistleblowing, the Australian Senate Select Committee on Public Interest Whistleblowing reached the conclusion that:

"...what is important is not the definition of the term, but the definition of the circumstances and conditions under which employees who disclose wrongdoing should be entitled to pro${ }^{13}$ See "Ensuring Protection: EU Guidelines On Human Rights Defenders" available at:

http://www.consilium.europa.eu/uedocs/cmsUpload/GuidelinesDefenders.p df [last accessed 27th November 2013.]

${ }^{14}$ The use of the expression "public interest" is not accidental here as the common law defence to actions for breach of confidence depends on the disclosure being in the public interest (see below).

${ }^{15}$ The Council of Europe's Committee on Legal Affairs and Human Rights (2009) defines whistleblowing as "concerned individuals sounding the alarm in order to stop wrongdoings that place fellow human beings at risk”. tection from retaliation" (Australian Senate Select Committee on Public Interest Whistleblowing, 1994) ${ }^{16}$.

It should be noted that this article focuses only on whistleblowing in an employment context. While citizens who raise concerns about wrongdoing in non-work situations also merit protection against reprisals, we believe that the case for recognising a separate category of lex specialis is strongest in relation to those who are broadly defined as workers, especially in the context of countries in the South where, due to the need to attract foreign direct investment, there may be less incentive to design such protection measures. Human rights defenders as a category are excluded from the scope of this article, since their critique may not pertain directly to their employment. Another caveat that needs to be highlighted is that our analysis pertains to the context of individuals facing the dilemma of whistleblowing. Thus trade unionists operating within the mandate of collective bargaining structures would also be excluded. Besides the general need to delimit the scope of the definition, the two excluded categories of individuals also already have lex specialis in terms of their positions.

Another issue that arises in relation to workplace reporting is whether it is necessary to distinguish internal from external reporting ${ }^{17}$. There are good practical reasons for doing so. For example, while disclosures to higher management might be perceived by supervisors as disloyal, it cannot be treated as a breach of the common law duty of confidence or fidelity ${ }^{18}$. Internal reporting would seem to offer advantages all round. The employer is given the chance to deal with concerns without external pressure and, from the worker's perspective, once a problem has been aired externally they are more likely to suffer reprisals. In addition, the public might gain from the speedy rectification of wrongdoing without the need for investigation or expenditure by government agencies ${ }^{19}$. Conversely, it could be argued that internal disclosures are not necessarily in the public interest since they facilitate cover-ups and may conceal systemic failures. In the context of the need for special protection we are necessarily focusing on the situation where internal reporting procedures have either been exhausted, or where the nature of the circumstance makes internal disclosure non-viable. Thus our attention is on the need to protect workers who have either decided or felt compelled to make an external disclosure in order to right a wrong or raise a concern.

\section{Why the Right to Blow the Whistle Is Important}

Perhaps the most compelling argument in favour of designing special protection for whistleblowing is that it may directly

\footnotetext{
${ }^{16}$ The current definition used by Transparency International (2013) is "the disclosure of information related to corrupt, illegal, fraudulent or hazardous activities being committed in or by public or private sector organisations (including perceived or potential wrongdoing) which are of concern to or threaten the public interest, to individuals or entities believed to be able to effect action".

${ }^{17}$ Some writers do not accept that internal disclosures amount to whistleblowing see Jubb (1999).

${ }^{18}$ The employee's implied obligations of loyalty or fidelity have evolved over the centuries and currently manifest themselves in the form of a duty to co-operate. This is clearly based on the premise that workers are engaged to promote the commercial interests of the employer. See Secretary of State for Employment v ASLEF (No. 2) [1972] QB 455.

${ }^{19}$ Thus a major policy issue for legislators has been to decide whether or not a statutory duty should be imposed on employers to establish and maintain appropriate whistleblowing procedures. Several statutes require public sector organizations to have such procedures, for example, Section 11 Protected Disclosures Act 2000 (New Zealand).
} 
promote the right to life. According to Agalgatti \& Krishna, the world's worst industrial disaster Bhopal, India, 1984 "is a tragic example of what could have been averted by alert whistleblowing" (Agalgatti \& Krishna, 2004). At this Union Carbide plant, where thousands died as a result of a gas leak, the concerns of workers and a journalist were ignored by the local authority. Detailed investigations revealed that series of warnings were disregarded and cost-cutting measures had adversely affected work conditions and the maintenance of safety systems. Similarly, the investigation into the Herald of Free Enterprise disaster outside Zeebrugge in 1987 found that employees had aired their concerns on five previous occasions about the ship sailing with its bow doors open. A member of staff had even suggested fitting lights to the bridge to indicate whether the doors were closed. The inquiry concluded: "If this sensible suggestion had received the serious consideration it deserved this disaster might well have been prevented" (Department of Transport, 1987).

The enquiry into the 1988 Piper Alpha oil platform disaster in the North Sea found that: "workers did not want to put their continued employment in jeopardy through raising a safety issue that might embarrass management" (Public inquiry, 1990).

In addition to helping to expose financial scandals, like those which occurred at $\mathrm{BCCI}^{20}$, Enron (Sterling, 2002) and WorldCom (Jeter, 2003), whistleblowing remains an important tool in the fight against corruption, which itself contributes to poverty (International Council for Human Rights Policy, 2009). Reduced levels of corruption would allow funds earmarked for infrastructure to be expended on projects rather than enriching contractors, administrators or politicians. Because corruption is notoriously difficult to detect and address through formal legal channels, especially in developing countries, it is vital to provide other means by which corrupt practices can be exposed. The opportunity to blow the whistle offers an additional mechanism for exposing financial and other forms of wrongdoing (Carr \& Lewis, 2010). Thus it is unsurprising that procedures have been introduced by many employers as an aspect of good corporate governance ${ }^{21}$. However, on a global scale, there is currently no statutory right to whistleblow, with only Norway imposing a general duty on employers to provide confidential reporting procedures ${ }^{22}$.

It has been argued elsewhere (Lewis, 2005) that reprisals against whistleblowers are a form of unequal treatment that constitutes a violation of human rights ${ }^{23}$. This is especially clear at EU level, where all the Equality Directives adopted under Article 13 EC place the right to equal treatment and non-discrimination on a human rights basis ${ }^{24}$. In the UK, Section 3 of

\footnotetext{
${ }^{20}$ The Bingham Inquiry (1992) found that there was a climate of intimidation and staff felt that they could not voice their concerns.

${ }^{21}$ On the UK position see Lewis (2006).

${ }^{22}$ Section 3(6) of the Work Environment Act 2005.

${ }^{23}$ According to Judge Ansell in Virgo Fidelis School $v$ Boyle [2004] IRLR 268 , subjecting a whistleblower to a detriment is a form of discrimination. This approach has been universally adopted in subsequent cases brought under Part IVA ERA 1996.

${ }^{24} \mathrm{~A}$ recital in their Preambles declares: The right to equality before the law and protection against discrimination for all persons constitutes a universal right recognized by the Universal Declaration of Human Rights, the United Nations Convention on the Elimination of all Forms of Discrimination against Women, the International Convention on the Elimination of all Forms of Racial Discrimination and the United Nations Covenants on Civil and Political Rights and on Economic, Social and Cultural Rights and by the European Convention for the Protection of Human Rights and Fundamental Freedoms, to which all Member States are signatories.
}

the Equality Act 2006 (EA, 2006) imposes a general duty on the Commission for Equality and Human Rights (EHRC) to encourage and support "the development of a society in which -(b) there is respect for and protection of each individual's human rights". The other limbs of this section can also be invoked in relation to whistleblowing: thus individuals need to be able to raise concerns about suspected wrongdoing if they are to maintain their "dignity and worth" and to "participate in society" ${ }^{25}$. However, if they suffer reprisals for doing so this would not only be disrespectful but such discrimination might limit their "ability to achieve their potential" 26 .

One of the most crucial factors relevant to our argument is the influx of multinational corporations into developing countries. In many instances this is creating unequal bargaining situations between communities and corporation to the grave detriment of citizens' security and, while the terms of the initial contract determining access may itself be flawed, it becomes vital to ensure the existence of adequate processes through which wrongdoing can be addressed. The newly emerging United Nations Framework on Multinational Corporations (articulated through the work of Special Representative Professor John Ruggie) seeks to address this issue through the requirement that corporate entities engage in human rights impact assessment prior to the commencement of operations. A second string of protection could be provided by insisting on the need for entities to create a grievance procedure. However, in light of the unequal bargaining positions that are likely to persist (with communities needing the employment provided by the company, and the state requiring the investment) it becomes particularly important to protect those who might be unable to raise concerns about wrongdoing through such mechanisms.

In the authors' opinion it is because whistleblowing is often in the interests of wider society that exceptional measures should be taken to facilitate it. In the context of general human rights development our focus has been exclusively on the relationship between state and citizen. Thus our conception of citizen security is necessarily framed within this paradigm. However with the growing recognition of the international personality of businesses in general and multinational corporations in particular, it is important to widen our view of who the key actors may be in an understanding of citizens' security. There is abundant evidence about the extent and nature of reprisals that have been suffered by whistleblowers in many countries over the years (Glazer \& Glazer, 1989; Rothschild \& Miethe, 1994) and research in both the US (Miceli, Near, \& Dworkin, 2008) and Australia (Brown, 2008) confirms that the fear of retaliation is one of the two main reasons given for not reporting perceived wrongdoing ${ }^{27}$. Unless a right to report suspected wrongdoing is given special status and adequate measures put in place to deter reprisals, the moral obligation ${ }^{28}$ to disclose wrongdoing will continue to conflict with the individual's selfinterest in preserving his or her job. In simple economic terms, where the personal cost of reporting is high and the benefit is low, whistleblowing will be discouraged ${ }^{29}$.

Some might argue that whistleblowers are already protected through the constitutional right of the freedom of speech. Al-

\footnotetext{
${ }^{25}$ See Section 3(c) \& (d) EA 2006 respectively.

${ }^{26}$ See Section 3(d) \& (a) EA 2006 respectively.

${ }^{27}$ The other main reason is the belief that no action would be taken.

${ }^{28}$ This is based on utilitarian arguments: it is acknowledged that in the deontological tradition of ethical theory a different view is taken.

${ }^{29}$ For a more sophisticated economic approach see Heyes \& Kapur (2009).
} 
though some countries provide a constitutional right to freedom of speech ${ }^{30}$, more general reliance is placed on human rights conventions $^{31}$. For example, Article 10(1) of the European Convention (ECHR) states that: "Everyone has the right to freedom of expression..."32 However, there can be little doubt that in most circumstances countries who impose limitations on freedom of speech are able to justify their actions under Article $10(2)^{33}$

In addition, Article 33 of the UN Convention on Corruption (UNCAC) 2003 provides that:

"Each State Party shall consider incorporating into its domestic legal system appropriate measures to provide protection against any unjustified treatment for any person who reports in good faith and on reasonable grounds to the competent authorities any facts concerning offences established in accordance with this Convention"34.

This protects all types of people and is not restricted to those who raise concerns from within an organisation. However, this measure also requires the discloser to have "reasonable grounds" and it is unclear whether these are to be subjectively or objectively determined. It almost goes without saying that in some situations it will be difficult to distinguish between strong suspicions and reasonable grounds. Another problem is the non-mandatory nature of the provision-it does not require State Parties to have such measures in place but only that they consider providing protection for those who report concerns. Thus it is possible for States to argue that they have considered art 33 but have decided not to adopt any measures as a consequence.

Mention should also be made of Article 5(c) of International Labour Organisation Convention No. 158 on Termination of Employment $^{35}$. This states that:

“...the filing of a complaint or the participation in proceedings against an employer involving alleged violation of laws or regulations or recourse to competent administrative authorities' does not provide a valid reason for dismissal" ${ }^{36}$.

This narrow formulation, which is only relevant to employment and does not deal with detriments short of dismissal, has a limited impact on those deliberating about whether or not to report suspected wrongdoing. Thus from the perspective of global state practice and that of key international organisations concerned with these issues, it could be argued that 1) whistleblowers necessarily need special protection in light of their role, and that 2) the mechanisms currently in existence are either inadequate or inappropriate to provide the necessary protection.

\footnotetext{
${ }^{30}$ It is a feature of whistleblowing disputes in the USA that government employees can comment on their employer and have free speech guaranteed under the first and fourteenth amendments.

${ }^{31}$ In their report to the Parliamentary Assembly entitled "The protection of whistle-blowers", the Council of Europe's Committee on Legal Affairs and Human Rights (2009) recommended that the Committee of Ministers "consider drafting a framework convention on the protection of 'whistle-blowers'” (Draft Recommendation 2.3).

${ }^{32}$ Guja v Moldova 2008. Application No. 14277/04 the European Court of Human Rights found an Article 10 violation when an employee of the Prosecutor General's office was sacked for leaking official letters to the press demonstrating political interference in ongoing investigations.

${ }^{33}$ Thus in $R v$ Shayler the House of Lords (as it then was) found that the UK's Official Secrets Act 1989 inhibited the defendant's freedom of expression under Article 10(1) but found that this was justified under Article $10(2)$.

${ }^{34}$ This came into force in 2005. See also the Council of Europe's Criminal and Civil Law Conventions on Corruption (both 1999).

${ }^{35} 68^{\text {th }}$ Session. 1982.

${ }^{36}$ Article 5 (c) ILO Convention No. 158 on Termination of Employment.
}

One limiting factor has been the traditional unitary view within common law jurisdictions concerning loyalty and trust at the workplace (Lewis, 2011). The assumed shared interests of employers and employees inhibited the acknowledgement of obligations towards the family, the workgroup, a professional body or trade union, to consumers or wider society. Further, there has been some confusion about the distinction between fiduciary obligations and good faith or fidelity terms implied into contracts of employment (Flanagan, 2008). Fiduciary obligations are not mutual but derive from equitable principles which require a person to act solely in the interests of another. By way of contrast, the duty of fidelity (or good faith) requires a party to take into consideration the interests of another but not necessarily to act in that other's interests. Thus, in theory, fiduciaries have a positive duty to disclose information which is not imposed on "ordinary" employees via implied contractual terms. Whether or not it is desirable in principle, it is clear that the distinction between "senior" and "ordinary" employees is difficult to sustain in practice. In Sybron Corporation $v$ Rochem $L t d^{37}$ which was argued on the basis of contractual rather than fiduciary obligations, the UK Court of Appeal held that a senior employee was in breach of duty in not disclosing that fellow employees had established rival organisations and were trading in competition with Sybron. This case provides authority for the proposition that there may be an implied contractual obligation to report the wrongdoings of others even if that requires the disclosure of one's own impropriety. Significantly, the duty to report does not appear to be dependent on the employer providing a suitable procedure.

The common law has never given workers a general right to disclose information about their employment. Even the revelation of non-confidential material could be regarded as undermining the implied duty of trust and give rise to action for breach of contract. In relation to confidential information obtained in the course of employment, the common law protects employers against disclosure through express and implied terms. For many years express terms prohibiting the disclosure of information acquired during employment have been standard in a wide range of industries ${ }^{38}$. Particular problems arose in the UK health service where staff had to reconcile a duty to raise concerns with specific "gagging clauses" in their contracts. In addition, some staff have to accommodate professional codes of practice which are enforced (through de-registration if necessary) by statutory bodies such as the UK's General Medical and the Nursing and Midwifery Councils. It seems almost inevitable that in some situations professional staff will perceive a conflict between the needs of patients and loyalty to the employer in the health service market. Similarly, the implied duty of fidelity can be used to prevent disclosures while the employment subsists. However, where employees have allegedly disclosed confidential information in breach of an express or implied term they may seek to invoke a public interest defence to a legal action. Although the common law allows the public interest to be used as a shield against an injunction or damages, we will see that it has been a weapon of uncertain strength (Cripps, 1994).

Since Initial Services $v$ Putterill ${ }^{39}$, the UK Court of Appeal has allowed an exception to the principle of non-disclosure of

\footnotetext{
${ }^{37}$ [1984] Ch 112.

${ }^{38}$ In some instances these existed alongside codes of conduct or ethics which encouraged the reporting of concerns about wrongdoing!

${ }^{39}$ (1968)1 QB 396.
} 
confidential information where there is "any misconduct of such a nature that it ought in the public interest to be disclosed to others". Here a sales manager was sued for breach of confidence to stop him passing documents relating to unlawful price-fixing to a national newspaper. However, the disclosure must be to someone who has an interest in receiving it and, in this case, Lord Denning was of the opinion that the media had a sufficient interest for these purposes. In Lion Laboratories $v$ Evans $^{40}$, two employees gave a national newspaper copy of internal documents doubting the reliability of the breathalysers manufactured by their employer. The company sought an injunction to prevent publication of the information on the grounds of breach of confidence. The action failed because the employees were found to have "just cause or excuse" for disclosure. However, the Court of Appeal indicated that the press might not always be the appropriate medium for disclosure.

Subsequently, in Re a Company's Application ${ }^{41}$, the High Court refused to grant an injunction preventing an employee in the financial services sector from disclosing confidential information about his company to a regulatory body, notwithstanding that the disclosure might be motivated by malice. Although Scott J. continued an injunction against general disclosure, he held that an employee's duty of confidence did not prevent them disclosing matters to regulatory authorities whose mandate included the duty to investigate. Thus, apart from the situation where an employee reports a breach of statutory duty to a relevant regulatory body, the common law has not provided reliable guidelines about what could be disclosed and to whom. However, one enduring feature of the public interest defence at common law is that it could be available even if a disclosure was tainted by malice. This may still be relevant because the whistleblowing statutes in the New Zealand, Ghana and South Africa normally deny protection to those who are shown to have acted in bad faith ${ }^{42}$.

Before we consider the impact of public interest disclosure legislation, we will again use the UK as an example to outline the types of statutory provisions which require individuals to blow the whistle. In addition to the general duty to report suspected acts of terrorism ${ }^{43}$, Sections 330-332 of the Proceeds of Crime Act 2002 makes it an offence not to disclose information about money laundering which is acquired "in the course of a business in the regulated sector". Similarly, Regulation 14 of the Management of Health and Safety at Work Regulations 1992 requires employees to inform employers of any work situation which could reasonably be considered to represent a serious and immediate danger to health and safety, and of shortcomings in the employer's protection arrangements which have not previously been reported ${ }^{44}$.

\section{Toward the Articulation of a Substantive Right to Whistleblow}

Many countries have introduced public interest disclosure or ${ }^{40}(1985]$ QB 526.

${ }^{41}$ [1989] IRLR 4.

${ }^{42}$ This was also the situation in the UK until 2013.

${ }^{43}$ See Terrorism Act 2000 Section 19 (as amended).

${ }^{44}$ Supported by Sections 44(1)(c) \& 100(1)(c) of the Employment Rights Act 1996 (ERA 1996) which provide that, where there is no safety representative or it is not reasonably practicable to raise the matter through such a representative or safety committee, it is unlawful to dismiss or take action short of dismissal against employees who "have brought to his attention, by reasonable means, circumstances connected with his work which he reasonably believed were harmful or potentially harmful to health and safety". whistleblower protection laws ${ }^{45}$. It is impossible to examine them in detail here but in order to make our case for a lex specialis human right to report suspected wrongdoing, we will highlight some of the basic shortcomings of existing legislation, before seeking to identify the key elements that need to be considered in the formulation of such a right at international level (Lewis, 2001). The UK's Public Interest Disclosure Act 1998 (PIDA, 1998) inserted a new Part IVA into the Employment Relations Act 1996 (ERA, 1996). PIDA 1998 was the model for South Africa's Protected Disclosures Act 2000 and has been regarded as an exemplary piece of legislation in debates in other countries $^{46}$. According to its Long Title, the sole purpose of this statute is "to protect individuals who make certain disclosures of information in the public interest" ${ }^{47}$. By way of contrast, a brief review of fourteen whistleblowing statutes in $2009^{48}$ revealed that their main objectives are to: protect disclosers (13 jurisdictions); facilitate/provide means for disclosures (11); investigate disclosures (5); encourage disclosures (4); address disclosures/ impropriety (4); provide a Fund for rewarding whistleblowers (1) ${ }^{49}$.

In relation to the types of wrongdoing that can be disclosed and by whom, it should be noted that some jurisdictions have decided as a matter of principle, not to deal with whistleblowing in the private sector ${ }^{50}$ or the security services. Since there is no clear demarcation between the public and private sectors and events have demonstrated that corruption and other malpractices occur in both, we suggest that there is no case for excluding the private sector from the scope of whistleblowing protection. There should be a right to report suspected wrongdoing wherever it occurs. Thus reporting should be allowed whether or not the suspected wrongdoing occurs outside a particular territory or legal jurisdiction ${ }^{51}$. This is important as a matter of principle and could have a particular impact in relation to concerns about the activities of foreign governments and transnational enterprises. Similarly, instead of excluding the security services altogether, countries might be allowed to have special rules for reporting suspected wrongdoing in relation to security matters $^{52}$. Another critical issue is whether protection should be

\footnotetext{
${ }^{45}$ Although paragraph 4 of the Draft Resolution contained in the Report by the Committee on Legal Affairs and Human Rights (2009) to the Parliamentary Assembly of the Council of Europe records that most member states have no comprehensive laws for the protection of whistleblowers.

${ }^{46}$ Including in the Netherlands, New Zealand and Australia, see Vandekerckhove 2006.

${ }^{47}$ This is also the sole objective of Queensland's Whistleblower Protection Act 1994.

${ }^{48}$ The countries are: the UK, Japan, South Africa, New Zealand, Canada, Ghana and eight Australian states/territories.

${ }^{49}$ The legislation in New South Wales, Victoria and Tasmania have all five objectives; the Northern Territory has four objectives; NZ and Ghana have three; Japan, Canada, Western Australia, South Australia and South Africa all have two and the Australian Capital Territory has one.

${ }^{50}$ The vast majority of the eight Australian states and territories exclude the private sector and it is not clear to what extent financial irregularities in the private sector are covered by the New Zealand legislation.

${ }^{51}$ Section 43B(2) ERA 1996 provides: ....it is immaterial whether the relevant failure occurred, occurs or would occur in the United Kingdom or elsewhere, and whether the law applying to it is that of the United Kingdom or any other country or territory.

${ }^{52}$ See Sections 12-14 Protected Disclosures Act 2000 (New Zealand). On 2nd October 2013 the Council of Europe Parliamentary Assembly adopted a resolution on "National Security and access to information". This underlines that "legitimate, well-defined national security interests" are valid grounds for withholding information held by public authorities, but invoking "national security" as a ground for secrecy should be subject to reasonable limits. Crimes such as murder, enforced disappearances, torture or abduction committed by state agents do not deserve to be protected as "state secrets”. However, it should be noted that existing European Convention rights frequently have a national security exemption.
} 
afforded to employees or a broader category of worker ${ }^{53}$. If a future instrument focuses only on employment relationships, it is suggested that rights should be given broadly to all persons who work for and receive remuneration from another person or the State ${ }^{54}$.

As regards what can be disclosed, legislators should adopt a broad approach to the definition of reportable matters and should allow disclosures about suspected past, current and future wrongdoing, irrespective of whether the information relates to the discloser or his or her employment context. Although it might be tempting to provide a right to report suspected "wrongdoing" and leave that word undefined, we believe this would cause significant practical difficulties. Potential disclosers are only likely to report if they know in advance they will be protected ${ }^{55}$ and this can be achieved by providing a watertight list of circumstances ${ }^{56}$. Given the widespread international support for the approach taken by the current UK legislation, we suggest that "wrongdoing" should cover the matters treated as "qualifying disclosures" in Section 43B(1) ERA 1996. These include: 1) a criminal offence; 2) a failure to comply with any legal obligation; 3) a miscarriage of justice; 4) danger to the health and safety of any individual; 5) damage to the environment; 6) the deliberate concealment of information tending to show any of the matters listed above ${ }^{57}$. It is critical to avoid additional "public interest" tests since this would create uncertainty and act as a disincentive to potential whistleblowers who may not be prepared to run the risk of a future court or tribunal reaching an adverse decision on such a notoriously subjective matter ${ }^{58}$.

There is also the important question of whether whistleblowers need to establish good faith as well as a reasonable suspicion that there was, is, or will be wrongdoing ${ }^{59}$. It would be unfortunate if the examination of motive deterred disclosures, especially in relation to health and safety or serious crimes. If individuals have an honest belief that information they disclose is true, their motive ought not to be relevant. The public interest is

${ }^{53}$ We note here that those who report concerns in their capacity as a trade union official should have statutory protection by virtue of that status. Often concerns about suspected wrongdoing will have a collective dimension but our case for the recognition of a lex specialis is in relation to individuals rather than trade unions.

${ }^{54}$ The UK legislation only protects "workers" as defined by Section $43 \mathrm{~K}$ ERA 1996. This does not include job seekers or volunteers.

${ }^{55}$ In this respect the EAT's recent decision in Cavendish Munro Professional Risks Management Ltd v Geduld [2010] IRLR 38 seems particularly unhelpful in drawing a distinction between a "disclosure" and a "communication".

${ }^{56}$ For this reason we would not use such categories as maladministration or mismanagement or such expressions as "serious wrongdoing".

${ }^{57}$ Paragraph 6.1.1 of the Draft Resolution contained in the Report by the Committee on Legal Affairs and Human Rights to the Parliamentary Assembly of the Council of Europe (2009) provides the following definition of protected disclosures: all bona fide warnings against various types of unlawful acts, including all serious human rights violations which affect or threaten the life, health, liberty and other legitimate interests of individuals as subjects of public administration or taxpayers, or as shareholders, employees or customers of private companies.

${ }^{58}$ Thus we agree with the view that: Relevant legislation must first and foremost provide a safe alternative to silence, whilst avoiding offering potential whistleblowers a 'shield of cardboard' which would entrap them by giving them a false sense of security. Para. 5, Draft Resolution contained in the Report by the Committee on Legal Affairs and Human Rights to the Parliamentary Assembly of the Council of Europe (2009).

${ }^{59}$ Good faith is no longer required for protection to be obtained under the UK legislation but lack of it can affect the amount of compensation awarded. The Enterprise and Regulatory Reform Act 2013 now makes protection for whistleblowers conditional on a public interest test being satisfied in all situations, including internal disclosures! best served if malicious reporting is addressed through denying protection to those who knowingly make false allegations ${ }^{60}$ with the possibility of disciplinary proceedings to follow. This may encourage individuals to disclose accurate information they would not have revealed but for a desire to inflict harm on others. However, that would arguably be an acceptable price to pay in order to encourage reporting of suspected wrongdoing. As regards disclosures that investigating bodies believe frivolous, vexatious or trivial, a refusal to take action would be justifiable but ought not to result in the removal of protection from the discloser.

The next issue is whether a right to whistleblow ought to be conditional on disclosures being made in a specified way to designated recipients: a feature of some existing legislation (Lewis, 2001). Although trade unionists might naturally prefer to raise concerns with their local official, many workers are not organised in such unions. Thus, while negotiated reporting procedures often give unions a significant role, whistleblowing legislation tends not to mention them. Making protection contingent on adherence to particular procedures is risky because such procedures may not be in place, may be defective or simply not communicated adequately. In relation to external disclosures, while it might be desirable that concerns are raised with a regulatory authority rather than the press, it is not always clear to potential whistleblowers who the appropriate regulator is, and that reporting to the media would not achieve the desired result more speedily. Indeed, whistleblowers can benefit from the ability of journalists to protect their sources ${ }^{61}$.

Related to this is the question of anonymity. It goes without saying that if a whistleblower's identity remains concealed they should not suffer any detriment for reporting. The major problem with anonymity is that it can inhibit investigations in a way that confidential disclosures would not. Yet confidentiality cannot always be guaranteed. Not only does it depend on trust in the competence and integrity of the recipient of a concern but the identity of an informant may become obvious from the nature of the inquiries made. Although it is important that whistleblowers feel confident enough to be identified, anonymous reporting would have be tolerated on the basis that it is better to have some information about suspected wrongdoing than none ${ }^{62}$.

If a right to report suspected wrongdoing acquires the special status argued for here, the question of remedy for its infringement follows. Arguably it is appropriate to underline the importance of raising concerns by making the victimization of whistleblowers a criminal offence ${ }^{63}$. Civil remedies would be less contentious, although even unlimited compensation may not stop reprisals or lead to their discontinuance. Thus it seems sensible to make victimization a tort and to provide for injunctive relief, remedial action and exemplary damages ${ }^{64}$.

\footnotetext{
${ }^{60}$ See Section 10 Whistleblower Protection Act 1993 (South Australia).

${ }^{61}$ See the supportive ruling of the European Court of Human Rights in Tillack v Belgium. 2007. Application No. 20477/05. In this case the journalist's sources had provided information about irregularities in the EU's anti-fraud office.

${ }^{62}$ Anonymous reporting may be the only reasonable option for whistleblowers in countries where the institutional environment is weak.

${ }^{63}$ Such an approach is reinforced by the fact that, in certain circumstances, harassment is already an offence, for example, under the UK's Protection from Harassment Act 1997

${ }^{64}$ In New Zealand Section 25 Protected Disclosures Act 2000 (PDA 2000) deals with victimisation by amending Section 66(l) of the Human Rights Act 1993 in order to protect persons (and relatives or associates) who: 1) intend to make or have made a disclosure or have encouraged disclosure by some other person under PDA 2000; or 2) have given information or evidence in relation to any complaint, investigation or proceeding arising out of a disclosure under PDA 2000. Under Sections 13 \& 14 of Ghana's Whistleblower Act 2006 complaints of victimization go to the Commission on Human Rights and Administrative Justice.
} 


\section{Lex Specialis and Its Substantive Content}

The precedent for creating special regimes for defined classes of persons is one of the fundamental axes along which public international law itself evolved ${ }^{65}$. Safeguards afforded to diplomats are probably among the earliest efforts to engage a system that would provide protection to those in a particularly vulnerable position ${ }^{66}$. The annals of history have numerous examples of peace-makers seeking an end to wars finding themselves in unfortunate positions behind enemy lines where they are hung, drawn and quartered. This persisted until it was realised that peace envoys needed special immunity to engage in their task without it being compromised $a b$ initio. As a result special regimes for diplomats evolved that shaped themselves into complicated systems of protection available in contemporary diplomatic law ${ }^{67}$.

Alongside the special protection afforded to diplomats, the rights of minorities were another equally important axis along which international law itself evolved. The Promise of St. Louis of France in 1250 is one of the earliest documented treaties that enshrines such protection (Thornberry, 1991). Mindful of the precarious position of the Maronites-a Christian minority living within the Muslim dominated Ottoman Empire, St Louis of France issued a promise in 1250 (renewed twice by successors in subsequent centuries) to protect these individuals from harm. The underlying notion appeared to be the need to accept that minorities (usually distinguishable from the rest of the population of the state on grounds of their distinct religion, language or traditions) would always be vulnerable to the tyranny of the majority ${ }^{68}$. There are several examples of such treaties which were regularly signed in various parts of Europe ${ }^{69}$, culminating in one of the most sophisticated legal systems for the protection of minorities under the auspices of the League of Nations (Stone, 1932). The dramatic failure of this regime is visible in the decimation of Jewish and other minorities during the Nazi conquest of Europe. Chastened by this experience, the new United Nations argued for a mainstreaming of rights rather than the fragmentation of regimes on different group bases. Thus the preamble and the actual Charter of the United Nations makes no mention of minority rights, stressing the rights of all instead. Despite this reluctance it is clear from the discussion above, that different categories of lex specialis continue to be the manner in which international law seeks to plug the reality gap between the stated and realisable rights of different classes of individuals.

Using this lens we argue that the nature of contemporary society justifies the need for the creation of a robust special mechanism for the protection of whistleblowers. The range of human rights violations perpetrated by multinationals is per-

\footnotetext{
${ }^{65}$ See generally, WG Grewe translated by M Byers (2000).

${ }^{66}$ Ibid. p.163ff.

${ }^{67}$ For a general insight into diplomatic law see generally, Frey \& Frey (1999).

${ }^{68}$ While there is no universally accepted definition of minorities, the following definition framed by UN Rapporteur Francesco Capotorti is considered indicative: A minority is a group that is numerically inferior to the rest of the population of a state, in a non-dominant position, whose members, being nationals of the state, possess ethnic, linguistic and religious characteristics that differ from the rest of the population, and who maintain, if only implicitly, a sense of solidarity directed towards preserving their identity see Capotorti (1977).

${ }^{69}$ See e.g. Convention for the Settlement of the Frontier between Greece \& Turkey 1881, full text available in M Hurst, Key Treaties of the Great Powers, 1814-1914.
}

haps unsurprising ${ }^{70}$ : they seek to operate within systems that would enable them to maximise their profits. The litigation against such corporations through the Alien Tort Claims Act ${ }^{71}$ in the United States of America and similar legislation in other parts of the world ${ }^{72}$, has stalled recently, removing a layer of protection that provided limited access. Providing protection to citizens that could potentially highlight violations taking place within the ambit of their workplace becomes a crucial cog in seeking greater accountability for actions that violate the inherent dignity and worth of all human beings.

\section{Protection in UN Based International Human Rights Based Treaty Law}

Under public international law and international human rights law a strong precedent exists for creating special protection for certain classes of individuals. This brief section seeks to reflect on existing special regimes, explaining the protection afforded and the mechanism created for overcoming barriers to access. The relevant human rights instruments are briefly considered below.

All nine fundamental human rights treaties seek to articulate a range of specific rights ${ }^{73}$. They also create specific state obligations to uphold these rights, and generate a system whereby a State-elected treaty-monitoring body is given the mandate to ensure compliance. Of these treaties, the following can be identified as offering distinct special protection to a class of individuals:

1) International Convention for the Elimination of All Forms of Racial Discrimination, 1965;

2) International Convention for the Elimination of All Forms of Discrimination Against Women, 1979;

3) Convention for the Rights of the Child, 1989;

4) International Convention for Migrant Workers and their Families, 1992;

5) International Convention on the Protection and Promotion of the Rights and Dignity of Persons with Disabilities, 2008.

The preambles of these treaties demonstrate their rationale as seeking to overcome the gap between the de jure situation of the class in question and their de facto position in society. Each treaty articulates a series of general human rights available to all and, in addition, specific rights that accrue to the category of people they seek to protect. The tension that inevitably exists with such regimes is the extent to which they can be generated without creating unfair discrimination against the rest of the population. This tension is best demonstrated in the context of

\footnotetext{
${ }^{70}$ This despite the clear articulation of an argument about the role that various non-state actors are obliged to play. For more see, Clapham (2006). Also see the latest attempt to regulate business Ruggie (2006).

${ }^{71} 28$ U.S.C. § 1350.

${ }^{72}$ For an update on the cases, their progress and the discussions they have entailed see http://www.business-humanrights.org/Home [last consulted November 27th 2013].

${ }^{73}$ These are: International Covenant on Economic, Social and Cultural Rights (1966); International Covenant on Civil and Political Rights (1966); International Convention on the Elimination of All Forms of Racial Discrimination (1965); Convention on the Elimination of All Forms of Discrimination against Women (1981); Convention against Torture and Other Cruel, Inhuman or Degrading Treatment or Punishment (1984); Convention on the Rights of the Child (1989); International Convention on the Protection of the Rights of All Migrant Workers and Members of Their Families (1990); International Convention on the Protection and Promotion of the Rights and Dignity of Persons with Disabilities (2006); International Convention for the Protection of All Persons from Enforced Disappearance (2006).
} 
the International Convention for the Elimination of All Forms of Racial Discrimination, which creates the obligation on states to create affirmative action measures to address the gap between those who are identifiable and face discrimination on racial grounds (identified broadly as covering race, ethnicity, decent, nationality and linguistic differences) ${ }^{74}$ and the rest of the population. The sub-article in question is 2(2):

"States Parties shall, when the circumstances so warrant, take, in the social, economic, cultural and other fields, special and concrete measures to ensure the adequate development and protection of certain racial groups or individuals belonging to them, for the purpose of guaranteeing them the full and equal enjoyment of human rights and fundamental freedoms. These measures shall in no case entail as a consequence the maintenance of unequal or separate rights for different racial groups after the objectives for which they were taken have been achieved"75.

However to ensure that the systems created do not justify segregation a la apartheid (Richardson, 1978) ${ }^{76}$, Article 1(4) seeks to highlight that such rights can only be enshrined in a positive context. Thus:

"Special measures taken for the sole purpose of securing adequate advancement of certain racial or ethnic groups or individuals requiring such protection as may be necessary in order to ensure such groups or individuals equal enjoyment or exercise of human rights and fundamental freedoms shall not be deemed racial discrimination, provided, however, that such measures do not, as a consequence, lead to the maintenance of separate rights for different racial groups and that they shall not be continued after the objectives for which they were taken have been achieved"77.

In recent years the Committee for the Elimination of Racial Discrimination (CERD) has sought to reiterate its mandate by identifying various groups that could be identified as needing further protection. Among these are: women facing multiple discrimination $^{78}$, the Roma ${ }^{79}$, indigenous peoples ${ }^{80}$ and noncitizens $^{81}$. What underlies the identification of these groups is that discrimination is often experienced by individuals on the basis of belonging to a particular sub-category.

The special protection afforded to women is questioned by some feminists who argue that the creation of a specific category of women's rights is detrimental because it promotes the view that these rights are somehow different from human rights (Bunch, 1990) $)^{82}$. Such individuals argue that gender-based

${ }^{74}$ Article 1.1. International Convention on the Elimination of All Forms of Racial Discrimination. For a clarification of the scope of this article see CERD General Comment XXXII "The Meaning and Scope of Special Measures in the International Convention of the Elimination of Racial Discrimination", $75^{\text {th }}$ session, August 2009.

${ }^{75}$ Article 2(2) International Convention on the Elimination of All Forms of Racial Discrimination. For more see Castellino (2006).

${ }^{76}$ The concern that this article seeks to address is that of segregation or "Bantustanisation".

${ }^{77}$ Article 1(4) International Convention on the Elimination of All Forms of Racial Discrimination.

${ }^{78}$ CERD. General Recommendation XXV on Gender Related Dimensions of Racial Discrimination. Fifty-sixth session, 2000,

${ }^{79}$ CERD. General Recommendation XXVII On Discrimination against Roma, $57^{\text {th }}$ session 2000

${ }^{80}$ CERD. General Recommendation XXIII On the Rights of Indigenous Peoples, $51^{\text {st }}$ session 1997.

${ }^{81}$ CERD. General Recommendation XI on Non-Citizens, 42 ${ }^{\text {nd }}$ Session, 1993 and General Recommendation XXX Discrimination Against Non-Citizens, $1^{\text {st }}$ October 2004.

${ }^{82}$ The slogan “Women’s Rights are human Rights” has been reflected upon much but recently got a public airing in Hillary Clinton's speech at the Beijing Conference in 1995, see H R Clinton, “Women's Rights Are Human Rights” in 29 Human Rights (2002) p. 2. rights ought to be mainstreamed rather than segregated (Charlesworth, Chinkin, \& Wright, 1991). There is evidence that putting women's rights into a separate category has not been the most adept way to overcome de facto distinctions that exist in society vis-à-vis the rights of women, especially in relation to family law, inheritance and property rights and questions of citizenship and nationality (Otto, 2009). However, by and large, the approach taken by the International Convention for the Elimination of All Forms of Discrimination Against Women (CEDAW) was to emphasise the value of seeking "elimination" of "all forms" of discrimination against women. It also took a clear position on a debate that continues to echo through society: the extent to which culture is a determining factor in the rights allocation (Donnelly, 2007; Castellino \& Dominguez Redondo, 2006). The position of the regime in framing state obligations in this respect is clear. In the language of 2(f) it underlines that:

"States Parties condemn discrimination against women in all its forms, agree to pursue by all appropriate means and without delay a policy of eliminating discrimination against women and, to this end, undertake":

... (f) To take all appropriate measures, including legislation, to modify or abolish existing laws, regulations, customs and practices which constitute discrimination against women ${ }^{83}$;

The Convention on the Rights of the Child (CRC) identifies the four principles that should provide the basis for regarding children as a special category in need of protection:

1) The Right to Life;

2) The Best Interests of the Child;

3) The principle of Non-Discrimination, and

4) The Principle of Participation ${ }^{84}$.

By way of contrast, the International Convention on Migrant Workers' and their Families addresses a different challenge by illuminating the issue of those who normally do not gain rights given by law to citizens. The traditional model of human rights has been based on the Rousseausque vision of the "social contract” between the individual and her/his state (Minnow, 19861987). This is reflected in the fact that the human rights treaties enshrine rights primarily intended for citizens or nationals of a state. However, it is clear that the de facto situation, especially in more developed societies, is that those who face the most persistent and widespread discrimination tend to be non-nationals ${ }^{85}$. The traditional position was that such individuals were somehow beyond the mandate of the state, except in relation to the broadest forms of protection. This position has been gradually eroded through realisation that lack of protection for this category of people constitutes such a fundamental loophole in the system as to undermine its efficacy and claim to uphold the rights and dignity of every individual. Most United Nations conventions now accept this position and will challenge States where persistent rights violations occur against migrant workers. The Migrant Workers' Convention goes a step further in addressing the issue of "undocumented workers", who are mostly invisible in the societies in which they live ${ }^{86}$. These individuals are particularly vulnerable and, while their status as migrant

\footnotetext{
${ }^{83}$ Article 2(f). For more see Sepper (2008-2009) pp. 585-640. On reservations see Schabas (1997) and Riddle, (2002-2003). For globalisation of women's rights see Resnik (2001-2002).

${ }^{84}$ As contained in Articles 2, 4, 9 and 12. For more see Van Bueren (1998).

${ }^{85}$ As discussed in the context of the General Comment formulated by CERD.

${ }^{86}$ See overview of migration and rights at

http://www.ohchr.org/EN/HRBodies/CMW/Pages/CMWIndex.aspx [last consulted February 2nd, 2010].
} 
workers gives them a legal personality of sorts, its realisation remains one of the great contemporary challenges of modern human rights law when societies are increasingly viewing the question of non-formalised migration in the context of security (Bales, 2005).

The International Convention on the Protection and Promotion of the Rights and Dignity of Persons with Disabilities as one of the most modern human rights documents, synthesises its articulation of rights as truly indivisible, encompassing economic, social cultural, civil as well as political rights. It offers a definition of discrimination in Article 2, which contains these elements:

“'Discrimination on the basis of disability' means any distinction, exclusion or restriction on the basis of disability which has the purpose or effect of impairing or nullifying the recognition, enjoyment or exercise, on an equal basis with others, of all human rights and fundamental freedoms in the political, economic, social, cultural, civil or any other field. It includes all forms of discrimination, including denial of reasonable accommodation..."87

\section{Protection through Non-Treaty Based Mechanisms}

Thus the principle underlying the United Nations treatybased system is clear: the articulation of legal obligations, the implementation of these in State jurisdictions and their oversight (monitoring) by a designated body. The United Nations human rights regime, however, also includes Charter basedbodies that operate more in line with investigative and research activities. The history of these mandates is interesting, particularly the manner in which the special regime holders have developed their own mandates and working conditions ${ }^{88}$.

Today, the United Nations Charter-based system can be said to operate on the principle of documenting, investigating, highlighting and seeking remedies for any of the following: 1) particular kinds of violations, such as torture and disappearances ${ }^{89}$; 2) contemporary issues that need articulating, such as extreme poverty and the lack of food ${ }^{90}$; 3) seeking to generate societywide discussions on contemporary problems, such as realising international solidarity or working on environmental issues ${ }^{91}$; or 4) seeking to highlight the position of particular groups in specifically vulnerable positions, such as minorities, indigenous peoples and human rights defenders ${ }^{92}$. It is the fourth category

\footnotetext{
${ }^{87}$ Article 2, International Convention on the Protection and Promotion of the Rights and Dignity of Persons with Disabilities, 2008.

${ }^{88}$ For more on these mechanisms and the evolution of their legal basis, see Domínguez Redondo (2005).

${ }^{89}$ See http://www2.ohchr.org/english/issues/torture/rapporteur/; for Arbitrary Detention see

http://www2.ohchr.org/english/issues/disappear/index.htm [last accessed 27th November 2013].

${ }^{90}$ For Extreme poverty see

http://www.ohchr.org/EN/HRBodies/CMW/Pages/CMWIndex.aspx; for Right to Food see http://www.ohchr.org/EN/Issues/Food/Pages/FoodIndex.aspx [last accessed 27th November 2013].

${ }^{91}$ For International Solidarity see

http://www2.ohchr.org/english/issues/isolidarity/index.htm; for Adverse Effects of the Movement and Dumping of Toxic and Dangerous Products and Wastes on the Enjoyment of Human Rights see

http://www2.ohchr.org/english/issues/environment/waste/index.htm [last accessed 27th November 2013].

${ }^{92}$ For the Minority Issues see

http://www2.ohchr.org/english/issues/minorities/expert/index.htm; for Indigenous Peoples see

http://www2.ohchr.org/english/issues/indigenous/rapporteur/; for Human Rights Defenders see

http://www2.ohchr.org/english/issues/defenders/index.htm [last accessed $27^{\text {th }}$ November 2013].
}

that is of interest to us in this article, and the best examples of such mandates are the following:

1) Special Rapporteur on the situation of human rights and fundamental freedoms of indigenous people ${ }^{93}$;

2) Representative of the Secretary-General on the human rights of internally displaced persons ${ }^{94}$;

3) Special Rapporteur on the human rights of migrants ${ }^{95}$;

4) Independent Expert on minority issues ${ }^{96}$; and

5) Special Rapporteur on Human Rights Defenders ${ }^{97}$.

The underlying purpose of identifying these groups/indiividuals is to be able to lift the veil of state sovereignty and highlight violations that are taking place within different national jurisdictions, at a universal level. The inherent premise is that articulating these categories at universal level has the benefit of creating awareness of a supervening structure of interlocutors who are keen to ensure that the rights of these categories are not forgotten. Writing in 1984, Alston was particularly concerned about the proliferation of new rights through the action of bodies such as the General Assembly (Alston, 1984). Others, too, have been concerned about the overt fragmentation of the international legal system (Koskenniemi \& Leino, 2002; Higgins, 2006; Craven, 2003). This proposal, we would argue, does not engage either of these two challenges: it does not propose any new rights, and does not propose a new system that would conflict with existing ones. Rather it is an attempt to consolidate the gains made by human rights law and ensure their applicability in the context of the ever-growing and ever more complicated circumstances of the workplace.

Despite the prominence of contemporary human rights mechanisms, it is important to note that lex specialis regimes existed in international law prior to such mechanisms. These mechanisms provided the theoretical justification and practical precedent for the creation of the global human rights system (Koskenniemi, 2001). Among traditional regimes that have existed for particular classes of people in international law are: protection against slavery ${ }^{98}$, protection for women and children

\footnotetext{
${ }^{93}$ See http://www2.ohchr.org/english/issues/indigenous/rapporteur/ [last accessed $27^{\text {th }}$ November 2013].

${ }^{94}$ For Internally Displaced Persons see

http://www2.ohchr.org/english/issues/idp/index.htm [last accessed $27^{\text {th }}$ November 2013].

${ }_{95}$ Available at http://www2.ohchr.org/english/issues/migration/rapporteur/ [last accessed $27^{\text {th }}$ November 2013].

${ }_{96}$ Available at

http://www2.ohchr.org/english/issues/minorities/expert/index.htm accessed $27^{\text {th }}$ November 2013].

${ }_{97}$ Available at: http://www2.ohchr.org/english/issues/defenders/index.htm [last accessed $27^{\text {th }}$ November 2013].

${ }^{98}$ For a range of legal standards on the issue of slavery and trafficking in the context of public international law see Slavery, Servitude, Forced Labour and Similar Institutions and Practices Convention of 1926; International Convention for the Suppression of the Traffic in Women of Full Age 1934; Protocol amending the Slavery Convention 1953; Supplementary Convention on the Abolition of Slavery, the Slave Trade, and Institutions and Practices Similar to Slavery 1957; Convention for the Suppression of the Traffic in Persons and of the Exploitation of the Prostitution of Others 1951; Protocol to Prevent, Suppress and Punish Trafficking in Persons, Especially Women and Children, Supplementing the United Nations Convention Against Transnational Organized Crime 2001; Protocol Against the Smuggling of Migrants by Land, Sea and Air, Supplementing the United Nations Convention Against Transnational Crime 2001; International Agreement for the Suppression of the "White Slave Traffic," 1904. Also see the United Nations Special Rapporteur on Contemporary Forms of Slavery, available at: http://www2.ohchr.org/english/issues/slavery/rapporteur/index.htm [last accessed $27^{\text {th }}$ November 2013].
} 
in times of war $^{99}$, protection of prisoners of war as a particular category under the laws of armed conflict, protection of soldiers ${ }^{100}$, and the protection of those living under occupation ${ }^{101}$. Many of the regimes created under the auspices of the laws of armed conflict continue to be operational today and are regularly called upon to explain/justify actions in the context of international and non-international armed conflict ${ }^{102}$. In addition to these, a modern regime has grown to protect the rights of refugees (The Geneva Convention for the Protection of Refugees, 1951) ${ }^{103}$ which now comes under the direct auspices of the United Nations High Commissioner for Refugees ${ }^{104}$. Some older Guidelines also exist for the protection of juveniles $^{105}$.

Under international law it would seem that regimes have been generated in response to the need to afford a specific kind of protection to a defined group of individuals, mindful that existing mechanisms are limited in affording them adequate protection. We suggest that for the reasons outlined in Section I, whistleblowers fall within this rationale: 1) they are definable as a group based on the type of role that they may adopt in their employment context and, 2) that the mechanisms that currently exist for the protection of their rights are of limited utility in the context of the particular precarious position they are likely to place themselves in. We also argue that the growing reach and influence of multinational corporations and the combined need to ensure human rights in the context of their operation in different theatres, creates a compelling case for the need to protect those who would blow the whistle about wrongdoing.

\section{Designing an International Regime for the Protection of Whistleblowers}

This poses the subsequent question as to the nature of the protection that ought to be created. The process of negotiating a treaty for special protection is complex and fraught with difficulties. It is also important to be mindful of the fragmentation

\footnotetext{
${ }^{99}$ For a range of international standards pertaining to this issue see Convention with Respect to the Laws and Customs of War on Land (Hague, II) (1899); Convention Respecting the Laws and Customs of War on Land (Hague IV) (1907); Declaration on the Protection of Women and Children in Emergency and Armed Conflict (1974); Office of United Nations High Commissioner for Refugees, Guidelines on International Protection: Gender-Related Persecution within the Context of Article 1a(2) of the 1951 Convention and Its 1967 Protocol Relating to the Status of Refugees (2002).

${ }^{100}$ For legal standards, contemporary issues and commentary on this issue see the website of the International Committee of the Red Cross, specifically,

http://www.icrc.org/Web/Eng/siteeng0.nsf/htmlall/section_ihl_protected_pe rsons_and_property?OpenDocument [last accessed $27^{\text {th }}$ November 2013].

${ }^{101}$ For more on the issue of occupation, including the relevant standards and commentary see the website of the International Committee of the Red Cross specifically http://www.icrc.org/Web/Eng/siteeng0.nsf/html/634KFC [last accessed 27th November 2013].

${ }^{102}$ These issues came to a head most recently in the context of Guantanamo Bay see Rose (2009).

${ }^{103}$ For key standards on the issue of Refugee Law see Convention relating to the Status of Refugees1954; Protocol Relating to the Status of Refugees 1967; Cartagena Declaration on Refugees 1984.

${ }^{104}$ For details on the mandate and operations of the Office of the United Nations High Commissioner for Refugees see

http://www.unhcr.org/cgi-bin/texis/vtx/home [last accessed 27th November 2013].

${ }^{105}$ The key international standards in this area are United Nations Rules for the Protection of Juveniles Deprived of their Liberty (1990); United Nations Guidelines for the Prevention of Juvenile Delinquency (The Riyadh Guidelines) (1990); and the United Nations Standard Minimum Rules for the Administration of Juvenile Justice (“The Beijing Rules”) (1985).
}

of international law into separate regimes that may be in conflict with one another. In addition, the creation of a treaty is a costly process that States are unlikely to be willing to bear. Against this, however, the expanding network of Special Rapporteurs offers a cost-effective if not efficient way of focussing attention upon the situation of whistleblowers. Unlike the human rights regimes discussed in subsections above, special rapporteurs and treaties created under international law enshrining these categories do not necessarily have an oversight body to ensure compliance, nor a named interlocutor who can act on their behalf. However, non-governmental organisations and some governments have often championed these rights and ensured that they are viewed in the same light as those that are specifically enshrined in more specific human rights conventions.

The value of International Declarations, too, cannot be understated. These usually precede the creation of a treaty, but even in instances where they have not led to the celebration of a Treaty among State parties, they are often an important statement of intent of the need of the values of international society. In this light it is worth briefly highlighting the following three international Declarations each of which seek to afford protection to specific classes of individuals:

1) Minorities ${ }^{106}$

2) Indigenous Peoples ${ }^{107}$

3) Human Rights Defenders ${ }^{108}$

These declarations could be classified as "emerging" owing to the fact that they remain "soft law" instruments rather than legally binding treaties. However, the trend in each of these is clear: identifying particular classes of individuals that need protection, articulating the specific nature of the rights that are at stake, and seeking to establish a regime that spells out available remedies in each context. The last of these is of particular interest to us, since it could be argued that they resemble, in clearest form, the category of whistleblowers.

\section{Conclusion: Implementation of Special Protection for the Right to Blow the Whistle}

Local cultural environments can play an important role in promoting the disclosure of wrongdoing (or otherwise) (Park, 2008) and an institutional environment that supports the values of accountability, transparency and the rule of law would seem to be a prerequisite for effective whistleblowing protection. In addition, these values would coincide with the basic conditions necessary within society for a robust regime that effectively protects the human rights of all to flourish. Clearly, the particularities of various States act as a bulwark against negotiating instruments at international level. However, this challenge has been overcome dramatically in the erection of international regimes that subvert the traditional notion of state sovereignty and contribute to the creation of universal values. In the specific context of whistleblowing, even where such statutes are introduced that take account of local cultural factors, they will not achieve their objectives if the public are unaware of them. On the basis that people are more likely to learn about a special status human right than the details of particular national laws,

\footnotetext{
${ }^{106}$ Declaration on the Rights of Persons Belonging to National or Ethnic, Religious or Linguistic Minorities (1993).

${ }^{107}$ Declaration on the Rights of Indigenous Peoples (2007).

${ }^{108}$ For an authoritative Fact-Sheet on the issue of Human Rights Defenders see http://www.ohchr.org/Documents/Publications/FactSheet29en.pdf [last accessed 27th November 2013].
} 
we advocate that the right to report where a worker has a reasonable suspicion ${ }^{109}$ that wrongdoing has taken place, is taking place or will take place, should be recognised as well as the existing pantheons of rights, such as the freedom of expression, which only offer limited protection.

Recognition of such a right would be most robust if reinforced by an agreed international standard, whether through the articulation of a Declaration or Guidelines that set out any restrictions that are considered to be legitimate and how the right can be enforced. In relation to possible restrictions, in order to get international support it might be necessary to allow countries to provide that reports relating to the security services etc. must be channelled through a designated statutory procedure. As regards enforcement, we believe that redress should be made available to people who believe that they have been victimised at any time ${ }^{110}$ for disclosing or attempting to disclose, and that those who exercise this right should be immune from civil $^{111}$ or criminal liabilities. For the right to be meaningful, it would also be appropriate to require states to establish a specialist public agency, for example, an Ombudsman for Public Interest Disclosures. Such a body could provide advice and be mandated with the task of educating the general public about the importance of exercising their right to "speak up" in appropriate circumstances. In addition, a specialist agency might be obliged to ensure that reports of suspected wrongdoing are investigated, that remedial action is taken where appropriate and could be an appropriate recipient of complaints about the victimisation of whistleblowers ${ }^{112}$.

Having outlined the bare ingredients of a lex specialis human right to whistleblow, we are aware that it has also been argued that workers should have a reciprocal duty to report wrongdoing $^{113}$. However, we believe there are practical reasons for rejecting such a notion. A legal duty to whistleblow would inevitably lead some conscientious people to make premature disclosures i.e. before they had sufficient grounds to believe that the information disclosed was true. Such precautionary reporting would be understandable as a means of avoiding defaulting on their obligation. However, according to our suggested formula, if honest belief could not be established the right would not be engaged and the discloser would have to face the consequences. Conversely, if a person fails to fulfil a duty to report suspected wrongdoing, the question arises about whether the sanctions should be civil or criminal. Whatever the answer, there would clearly be difficulties where one person performed their duty to report but a large number of others, who were

\footnotetext{
${ }^{109}$ As mentioned above, this test would be satisfied if a person had an honest belief that the information disclosed was true. We prefer this to a "reasonable grounds" formula which might encourage people to investigate rather than report their suspicions to others who are in a better position to do so. For a vivid example of the problems that can arise where a whistleblower tries to establish "reasonable grounds" see Bolton School v Evans [2006] IRLR 500.

${ }^{110}$ For example, at the hiring stage as well as during and after employment. ${ }^{111}$ At present it would appear that if a reasonable belief turned out to be incorrect, defamation proceedings could be brought against a worker who has made a protected disclosure. Where there has been sufficient publication of a concern, a discloser who failed to establish the truth of the allegations would have to rely on the defence of qualified privilege.

${ }^{112}$ For an example, see the duties of Canada's Public Sector Integrity Commissioner listed in Section 22 of the Public Servants Disclosure Act 2005.

${ }^{113}$ Paragraph 3.9 of the British Standards Institute Code of Practice s (2008) states: "Organisations should not make it a requirement that employees blow the whistle as such a duty is unlikely to bolster staff confidence in the arrangements or help foster or embed a more open and accountable culture”.
}

apparently in the same position, failed to do so.

In arguing for the recognition for a lex specialis human right for workers to blow the whistle, we have accepted that it would be more difficult to provide adequate mechanisms for protecting freedom of speech outside the employment context. Yet workers are not the only citizens to observe wrongdoing or malpractice in society. Indeed, existing legislation deals with the complaints about discrimination in education, premises, goods, facilities and services. There can be little doubt that giving special status to workers who "speak up" would help to create a more positive cultural attitude towards whistleblowing generally ${ }^{114}$. It would send an important general message about the practical value of human rights in modern society and would add a dimension to the notion of "security" and citizens' rights that is currently ignored.

\section{REFERENCES}

Agalgatti, B., \& Krishna, S. (2004). Business Ethics (Concepts and Practices) (4th ed.). Pune: Nirali Prakashan.

Alston, P. (1984). Conjuring up new human rights: A proposal for quality control. American Journal of International Law, 78, 607-621.

An-Na'im, A. A., Madigan, A., \& Minkley, G. (1997). Cultural transformations and human rights in Africa: A preliminary report. Emory International Law Review, 11, 287-350

Australian Senate Select Committee on Public Interest Whistleblowing, (1994). In the Public Interest AGPS, Canberra.

Bales, K. (2005). Understanding global slavery: A reader. London: University of California Press.

Bingham, L. J. (1992). The inquiry into the supervision of the Bank of Credit and Commerce International. London: HMSO.

British Standards Institute (2008). Code of practice on whistleblowing arrangements. London: PAS.

Brown, A. (2008). Whistleblowing in the Australian public sector. Canberra: Australian National University.

Bruce, V., \& Young, A. (1998). In the eye of the Beholder: The science of face perception. Oxford: Oxford University Press.

Bunch, C. (1990). Women's rights as human rights: Towards a re-vision of human rights. Human Rights Quarterly, 12, 486-498. http://dx.doi.org/10.2307/762496

Capotorti, F. (1977). Special Rapporteur. Study on the Rights of Persons Belonging to Ethnic, Religious and Linguistic Minorities. UN.

Carr, I., \& Lewis, D. (2010). Combating corruption through employment law and whistleblower protection. Industrial Law Journal, 39, $1-30$.

Castellino, J., \& Domínguez Redondo, E. (2006). Minority rights in Asia: A comparative legal analysis. Oxford: Oxford University Press. http://dx.doi.org/10.1093/acprof:oso/9780199296057.001.0001

Castellino, J. (2006). A re-examination of the international convention for the elimination of all forms of racial discrimination. Revista Iberoamericana de Derechos Humanos, 2, 1-29.

Charlesworth, H., Chinkin, C., \& Wright, S. (1991). Feminist Approaches to international law. American Journal of International Law, 85, 613-645. http://dx.doi.org/10.2307/2203269

Clapham, A. (2006). Human rights obligations of non-state actors. Oxford: Oxford University Press. http://dx.doi.org/10.1093/acprof:oso/9780199288465.001.0001

Clinton, H. R. (2002). Women's rights are human rights. Human Rights, 29, 2.

Council of Europe's Committee on Legal Affairs and Human Rights (2009). Report to the Parliamentary Assembly "The protection of whistle-blowers". Strasbourg, Doc. 12006.

Craven, M. (2003). Unity, diversity and the fragmentation of interna-

\footnotetext{
${ }^{114}$ One way of endorsing the legitimacy of whistleblowing and encouraging it is to offer financial rewards. Such an approach can be found in the legislation in the USA, South Korea (in relation to fraud) and, more generally, in Ghana.
} 
tional law. Finnish Yearbook of International Law, 14, 3-34.

Cripps, Y. (1994). The legal implications of disclosure in the public interest: An analysis of prohibitions and protections. London: Sweet \& Maxwell.

Department of Transport (1987). Court of Enquiry No 8074. London: HMSO.

Domínguez Redondo, E. (2005). Los procedimientos públicos especiales de la comisión de derechos humanos de Naciones Unidas. Valencia: Tirant Lo Blanch.

Donnelly, J. (2007). International Human Rights (3rd ed.). London: Perseus Book Group.

Donoho, D. L. (1990-1991). Relativism versus universalism in human rights: The search for meaningful standards. Stanford Journal of International Law, 27, 345-392.

Durham, H. (2002). Women, armed conflict and international law. International Review of the Red Cross, 847, 655-659.

Flanagan, R. (2008). The (fiduciary) duty of fidelity. Law Quarterly Review, 124, 274-298.

Francioni, F. (2007). Access to justice as a human right. New York: Oxford University Press.

Gardam, J., \& Jarvis, M. (2001). Women, armed conflict and international law. The Hague: Kluwer Law International.

Glazer, M., \& Glazer, B. (1989). The whistleblowers: Exposing corruption in government and industry. New York: Basic Books.

Heyes, A., \& Kapur, S. (2009). An economic model of whistle-blower policy. Journal of Law, Economics \& Organisations, 25, 157-182.

Higgins, R. (2006). A Babel of judicial voices? Ruminations from the bench. International \& Comparative Law Quarterly, 55, 791-804.

Hurst, M. (1972). Key treaties of the great powers, 1814-1914. California: David \& Charles Press.

International Council for Human Rights Policy (2009). Corruption and Human Rights: Making the Connection.

http://www.ichrp.org/files/reports/40/131_web.pdf

Jeter, L. (2003). Disconnected: Deceit and Betrayal at WorldCom. New Jersey: John Wiley \& Sons.

Jubb, P. (1999). Whistleblowing: A restrictive definition and interpretation. Journal of Business Ethics, 21, 77-94. http://dx.doi.org/10.1023/A:1005922701763

Koskenniemi, M., \& Leino, P. (2002). Fragmentation of international law? Postmodern anxieties. Leiden Journal of International Law, 15, 553-579.

Koskenniemi, M. (2001). The gentle civilizer of nations: The rise and fall of international law 1870-1960. Cambridge: Cambridge University Press. http://dx.doi.org/10.1017/CBO9780511494222

Lewis, D. (2005). Providing rights for whistleblowers: Would an antidiscrimination model be more effective? Industrial Law Journal, 34, 239-252. http://dx.doi.org/10.1093/indlaw/dwi020

Lewis, D. (2006). The contents of whistleblowing/confidential reporting procedures in the UK: Some lessons from empirical research. Employee Relations, 28, 76-86.

http://dx.doi.org/10.1108/01425450610633073

Lewis, D. (2001). Whistleblowing at work: On what principles should legislation be based? Industrial Law Journal, 30, 169-193. http://dx.doi.org/10.1093/ilj/30.2.169

Lewis, D. (2011). Whistleblowing in a changed legal climate: Is it time to revisit our approach to trust and loyalty at the workplace? Business Ethics: A European Review, 20, 71-87.

Lewis, H. (1995). Between irua and female genital mutilation: Feminist human rights discourses and the cultural divide. Harvard Human Rights Journal, 8, 1-56.

Miceli, M., Near, J., \& Dworkin, T. (2008). Whistle-blowing in organizations. New York: Routledge.

Minow, M. (1987). Interpreting rights: An essay for rober cover. Yale Law Journal, 96, 1860-1915. http://dx.doi.org/10.2307/796400

Morsink, J. (2009). Inherent human rights: Philosophical roots of the universal declaration. Philadelphia, PA: University of Pennsylvania Press.

Morsink, J. (1999). The universal declaration of human rights: Origins, drafting and intent. Philadelphia, PA: University of Pennsylvania Press

Otto, D. (2009). The exile of inclusion: Reflections on gender issues in international law over the last decade. Melbourne Journal of International Law, 10, 11-26

Park, H. (2008). Cultural orientation and attitudes toward different forms of whistleblowing. Journal of Business Ethics, 82, 929-939. http://dx.doi.org/10.1007/s10551-007-9603-1

Public inquiry into the Piper Alpha disaster. (1990). CM 1310 HMSO, London.

Resnik, J. (2001-2002). Categorical federalism: Jurisdiction, gender and the globe. Yale Law Journal, 111, 619-680. http://dx.doi.org/10.2307/797544

Rhode, D. L. (2004). Access to justice. Oxford: Oxford University Press.

Richardson, H. J. (1978). Self-determination, international law and the South African Bantustan policy. Columbia Journal of Transnational Law, 17, 185-220.

Riddle, J. (2002-2003). Making CEDAW universal: A critique of CEDAW's reservation regime under article 28 and the effectiveness of the reporting process. Georgetown Washington International Law Review, 34, 605-638.

Rose, D. (2009). Guantanamo: America's war on human rights. London: Faber and Faber.

Rothschild, J., \& Miethe, T. (1994). Whistle-blowing as resistance in modern work organisations' in resistance and power in organisations. In J. Jermier, et al. (Eds.). London: Routledge.

Ruggie, J. (2006). Interim Report of the Special Representative of the Secretary-General on the Issue of Human Rights and Transnational Corporations and Other Business Enterprises, U.N. Doc. E/CN.4/2006/97.

Schabas, W. A. (1997). Reservations to the convention on the elimination of all forms of discrimination against women and the convention on the rights of the child. William \& Mary Journal of Women \& Law, 3, 79-112.

Sepper, E. (2008-2009). Confronting the sacred and unchangeable: The obligation to modify cultural patterns under the women's discrimination treaty. University of Pennsylvania Journal of International Law, 30, 585-640.

Sterling, T. (2002). The Enron scandal. New York: Nova Science Publishing.

Stone, J. (1932). Procedure under the minorities treaties. American Journal of International Law, 26.

Thornberry, P. (1991). International law and the rights of minorities. Oxford: Clarendon Press.

Transparency International (2013). International principles for whistleblowing legislation. Berlin: Transparency International.

Van Bueren, G. (1998). The international law on the rights of the child London: Martinus Nijhoff.

Vandekerckhove, W. (2006). Whistleblowing \& organisational social responsibility: A global assessment. Aldershot: Ashgate.

\section{International Legal Documents}

Additional Protocols to the Geneva Conventions 1949 (1977) Final Record of the Diplomatic Conference of Geneva of 1949, Vol. I, Federal Political Department, Bern, 205-224.

Cartagena Declaration on Refugees, Nov. 22, 1984, Annual Report of the Inter-American Commission on Human Rights, OAS Doc. OEA/Ser.L/V/II.66/doc.10, rev. 1, at 190-93 (1984-85), 17 April 1998.

Convention against Torture and Other Cruel, Inhuman or Degrading Treatment or Punishment, G.A. res. 39/46, annex, 39 U.N. GAOR Supp. (No. 51) at 197, U.N. Doc. A/39/51 (1984), entered into force June 26, 1987.

Convention Concerning Indigenous \& Tribal Peoples in Independent Countries (ILO No. 169), 72 ILO Official Bulletin 59, entered into force September 5, 1991.

Convention concerning the Prohibition and Immediate Action for the Elimination of the Worst Forms of Child Labour (ILO No. 182), 38 ILM 1207 (1999), entered into force Nov. 19, 2000.

Optional Protocol to the Convention on the Rights of the Child on the involvement of children in armed conflicts, General Assembly Resolution 54/263, Annex I, 54 U.N. GAOR Supp. (No. 49) at 7, UN Doc. A/54/49, Vol. III (2000), entered into force February 12, 2002. 
Convention for the Settlement of the Frontier between Greece \& Turkey 1881, full text available in M Hurst, Key Treaties of the Great Powers, 1814-1914 (California, David \& Charles Press, 1972) at 592.

Convention for the Suppression of the Traffic in Persons and of the Exploitation of the Prostitution of Others, 96 UNTS 271, entered into force July 25, 1951.

Convention on the Elimination of All Forms of Discrimination against Women, General Assembly Resolution 34/180, 34 UN GAOR Supp. (No. 46) at 193, U.N. Doc. A/34/46, entered into force Sept. 3, 1981.

Convention on the Rights of the Child, G.A. res. 44/25, annex, $44 \mathrm{UN}$ GAOR Supp. (No. 49) at 167, UN Doc. A/44/49 (1989), entered into force Sept. 2, 1990.

International Convention on the Protection of the Rights of All Migrant Workers and Members of Their Families, G.A. res. 45/158, annex, 45 UN GAOR Supp. (No. 49A) at 262, UN Doc. A/45/49 (1990), entered into force July 1, 2003.

Convention relating to the Status of Refugees, 189 UNTS 150, entered into force April 22, 1954.

Protocol Relating to the Status of Refugees, 606 UNTS 267, entered into force Oct. 4, 1967.

Convention Respecting the Laws and Customs of War on Land (Hague IV) (18 October, 1907), entered into force January 26, 1910.

Convention with Respect to the Laws and Customs of War on Land (Hague, II) (29 July 1899), entered into force September 4, 1900.

Declaration on the Protection of Women and Children in Emergency and Armed Conflict, General Assembly Resolution 3318 (XXIX), 29 UN GAOR Supp. (No. 31) at 146, UN Doc. A/9631 (1974).

Declaration on the Rights of Disabled Persons, General Assembly Resolution 3447 (XXX), 30 UN GAOR Supp. (No. 34) at 88, UN Doc. A/10034 (1975).

International Convention on the Protection and Promotion of the Rights and Dignity of Persons with Disabilities, General Assembly Resolution 61/106, Annex I, UN GAOR, 61st Sess., Supp. No. 49, at 65, UN Doc. A/61/49 (2006), entered into force May 3, 2008.

Declaration on the Rights of Persons Belonging to National or Ethnic, Religious or Linguistic Minorities, General Assembly Resolution 47/135, annex, 47 UN GAOR Supp. (No. 49) at 210, UN Doc. A/47/49 (1993).

First Optional Protocol to the International Convention on the Protection and Promotion of the Rights and Dignity of Persons with Disabilities, General Assembly Resolution 61/106, Annex II, UN GAOR, 61st Sess., Supp. No. 49, at 80, UN Doc. A/61/49 (2006), entered into force May 3, 2008.

Geneva Conventions on the Laws of Wars 1949 Final Record of the Diplomatic Conference of Geneva of 1949, Vol. I, Federal Political Department, Bern pp. 205-224.

Geneva Declaration of the Rights of the Child of 1924 adopted Sept. 26, 1924, League of Nations O.J. Spec. Supp. 21, at 43 (1924).

Guiding Principles on Internal Displacement, UN Doc. E/CN.4/1998/ 53/Add.2 (1998).

International Agreement for the Suppression of the "White Slave Traffic”, 18 May 1904, 35 Stat. 1979, 1 LNTS 83, entered into force 18 July 1905.

International Convention for the Suppression of the Traffic in Women of Full Age, Oct. 11, 1933, 150 LNTS, entered into force Aug. 24, 1934.

International Convention on the Elimination of All Forms of Racial Discrimination, 660 UNTS 195, entered into force Jan. 4, 1969.

International Convention on the Protection and Promotion of the Rights and Dignity of Persons with Disabilities, G.A. Res. 61/106, Annex I, U.N. GAOR, 61st Sess., Supp. No. 49, at 65, UN Doc. A/61/49 (2006), entered into force May 3, 2008.

International Convention for the Protection of All Persons from En- forced Disappearance, G.A. res. 61/177, UN Doc. A/RES/61/177 (2006) adopted Dec. 20, 2006.

International Convention on the Protection of the Rights of All Migrant Workers and Members of Their Families, General Assembly Resolution 45/158, annex, 45 UN GAOR Supp. (No. 49A) at 262, UN Doc. A/45/49 (1990), entered into force July 1, 2003.

International Covenant on Civil and Political Rights, G.A. res. 2200A (XXI), 21 UN GAOR Supp. (No. 16) at 52, UN Doc. A/6316 (1966), 999 UNTS 171, entered into force Mar. 23, 1976.

International Covenant on Economic, Social and Cultural Rights, G.A. res. 2200A (XXI), 21 UN GAOR Supp. (No. 16) at 49, U.N. Doc. A/6316 (1966), 993 UNTS 3, entered into force Jan. 3, 1976.

Guidelines on International Protection: Gender-Related Persecution within the Context of Article 1a(2) of the 1951 Convention and Its 1967 Protocol Relating to the Status of Refugees, UN Doc. HCR/ GIP/02/01 (2002).

Optional Protocol to the Convention on the Elimination of All Forms of Discrimination against Women, General Assembly Resolution 54/4, annex, 54 UN GAOR Supp. (No. 49) at 5, U.N. Doc. A/54/49 (Vol. I) (2000), entered into force Dec. 22, 2000.

Optional Protocol to the Convention on the Rights of the Child on the sale of children, child prostitution and child pornography, General Assembly Resolution 54/263, Annex II, 54 U.N. GAOR Supp. (No. 49) at 6, U.N. Doc. A/54/49, Vol. III (2000), entered into force January 18, 2002.

United Nations Rules for the Protection of Juveniles Deprived of their Liberty, General Assembly Resolution 45/113, annex, 45 UN GAOR Supp. (No. 49A) at 205, U.N. Doc. A/45/49 (1990).

Proposed American Declaration on the Rights of Indigenous Peoples (approved by the Inter-American Commission on Human Rights, $26^{\text {th }}$ February 1997 Doc. No. OEA/Ser/L/V/II.95 Doc. 6 (1997).

Protocol Against the Smuggling of Migrants by Land, Sea and Air, Supplementing the United Nations Convention Against Transnational Crime, G.A. Res. 55/25, annex III, UN GAOR, 55th Sess., Supp. No. 49, at 65, UN Doc. A/45/49 (Vol. I) (2001), entered into force Jan. 28, 2004.

Protocol amending the Slavery Convention, 182 UNTS 51, entered into force December 7, 1953.

Protocol to Prevent, Suppress and Punish Trafficking in Persons, Especially Women and Children, Supplementing the United Nations Convention Against Transnational Organized Crime, G.A. Res. 25, annex II, UN GAOR, 55th Sess., Supp. No. 49, at 60, U.N. Doc. A/45/49 (Vol. I) (2001), entered into force Dec.25, 2003.

Slavery, Servitude, Forced Labour and Similar Institutions and Practices Convention of 1926 (Slavery Convention of 1926), 60 LNTS 253, entered into force March 9, 1927.

Supplementary Convention on the Abolition of Slavery, the Slave Trade, and Institutions and Practices Similar to Slavery, 226 UNTS 3, entered into force April 30, 1957

The Promise of St. Louis of France, 1250.

United Nations Declaration on the Rights of Indigenous Peoples General Assembly Resolution 61/295, UN Doc. A/RES/47/1 (2007).

United Nations Guidelines for the Prevention of Juvenile Delinquency (The Riyadh Guidelines), General Assembly Resolution 45/112, annex, 45 UN GAOR Supp. (No. 49A) at 201, UN Doc. A/45/49 (1990).

United Nations Rules for the Protection of Juveniles Deprived of their Liberty, G.A. res. 45/113, annex, 45 UN GAOR Supp. (No. 49A) at 205, UN Doc. A/45/49 (1990).

United Nations Standard Minimum Rules for the Administration of Juvenile Justice ("The Beijing Rules"), General Assembly Resolution 40/33, annex, 40 U.N. GAOR Supp. (No. 53) at 207, UN Doc. A/40/53 (1985). 